\title{
Acid Mine Drainage Contamination of the Ur Impoundment: Environmental Geochemistry
}

\author{
Irina Myagkaya ${ }^{1,{ }^{*}, \text { Maria Gustaytis }}{ }^{1}$, Ivan Kirichenko $^{1}$, Bagai-ool Saryg-ool ${ }^{1}$, and Elena \\ Lazareva $^{1}$ \\ ${ }^{1}$ V.S. Sobolev Institute of Geology and Mineralogy, Russian Academy of Sciences, 3, Akademik \\ Koptyug str., Novosibirsk, 630090, Russia
}

\begin{abstract}
Water, particulate matter, and bottom sediments of the Ur impoundment used for fishing have been analyzed in terms of environmental geochemistry. The impoundment is located within the dispersion train of gold-bearing sulfide tailings at the Ur ore field and has been contaminated by acid mine drainage (AMD). The depth-dependent distribution of elements in the bottom sediments corresponds to (1) premining, (2) early mining, and (3) post-mining (present) stages. Sediment enrichment in $\mathrm{Cu}, \mathrm{Cd}, \mathrm{Fe}, \mathrm{Pb}, \mathrm{Zn}, \mathrm{As}$ and $\mathrm{Hg}$ depends on their speciation and migration patterns in water. The concentrations of many elements in water and bottom sediments exceed maximum allowable values. $\mathrm{Hg}$ occurring as the most toxic methyl compound poses the greatest hazard.
\end{abstract}

\section{Introduction}

The environment of residential and recreational areas has received progressively increasing recent attention [1]. All urban areas are exposed to pollution from gases emitted by vehicles, heating facilities, etc., as well as to cumulative pollution [2]. Pollution can accumulate in dispersion trains of sulfide tailings left by mining and ore processing [3], which spread for tens of kilometers along rivers and store heavy metals and other contaminants [4]. It is challenging to assess total contamination in ore fields where industrial pollution superimposes over naturally high enrichments in potentially toxic elements [5].

Au-bearing barite-Cu-Zn pyrite ores at the Novo-Ursk sulfide deposit, as well as their weathering profiles were mined and processed for more than 80 years. The cyanide wastes at the Ursk tailings site were dumped in 2 piles exposed to rainfall and floods that produce a dispersion train [6-8]. The wastes are drained by a natural creek which transforms into an AMD (pH 1.9) with high concentrations (ppm) of $3600 \mathrm{SO}_{4}{ }^{2-},>26 \mathrm{Al}, 780 \mathrm{Fe}, 0.63 \mathrm{As}, 2.5$ $\mathrm{Cu}, 11 \mathrm{Zn}, 18 \mathrm{Cd}, 110 \mathrm{~Pb}$ and $11.4 \mathrm{ppb} \mathrm{Hg}$ [7]. The AMD flows into the Ur River impounded $3 \mathrm{~km}$ downstream of the AMD discharge, while the pond is a traditional local fishing place. The Ur water regains its natural background composition $5 \mathrm{~km}$ downstream of the AMD inlet [4]. The aim is to estimate $\mathrm{Cu}, \mathrm{Cd}, \mathrm{Fe}, \mathrm{Pb}, \mathrm{Zn}, \mathrm{As}$ and $\mathrm{Hg}$ contamination of the pond bottom sediments.

\footnotetext{
* Corresponding author: i_myagkaya@igm.nsc.ru
} 


\section{Methods}

We sampled water, particulate matter, and bottom sediments in the Ur impoundment located $3 \mathrm{~km}$ downstream of the AMD discharge. Water was filtered through a $0.45 \mathrm{~lm}$ Sartorius Stedim filters and then poured in plastic vials and acidified with $\mathrm{HNO}_{3 \text { conc }}$ at 4:1000. Water sampled for $\mathrm{Hg}$ was collected into glass vials and acidified as well as above. Some water samples were left unacidified for determination of major ions by ion chromatography, on a 883 Basic IC Plus chromatograph, at the NIIC SB RAS (Novosibirsk, analyst Romanova T.E.). The concentrations of elements in natural water were determined by ICP-MS on an Agilent 7500 spectrometer, at the LIN SB RAS (Irkutsk, analyst E.N. Vodneva). Bottom sediments were collected with a hollow polypropylene tube $(4.5 \mathrm{~cm}$ in diameter, $50 \mathrm{~cm}$ long) plunged into sediments. The retrieved core was then wrapped in polyethylene film and divided into halves in the laboratory. One half was cut into $0.2 \mathrm{~cm}$ thick slabs; the specimens were air dried at $20-25^{\circ} \mathrm{C}$ and ground in a mortar. The other half was placed into aluminum capsules for scanning by SR-XRF at every $1 \mathrm{~mm}$ $[8,9]$, on a VEPP-3 system, at the Analytical Center of the BINP SB RAS (Novosibirsk). The results were checked against external standards (compared to the sum of sequentially extracted species in reference materials). Element contents in bottom sediments and in particulate matter were determined by AAS on a Solar M6 spectrometer, at the IGM SB RAS Analytical Center (analyst L.N. Bukreeva). Six samples of sediments from the upper (2-4 mm, 18-22 mm, 42-44 mm), middle (64-66 mm, 132-136 mm) and lower (248-250 $\mathrm{mm}$ ) core parts, in $0.5 \mathrm{~g}$ specimens, were studied for speciation of elements by sequential extraction. The extraction procedure consisted of 7 steps, with the water-soluble $\left(\mathrm{H}_{2} \mathrm{O}_{\text {dist }}\right)$, exchangeable $\left(1 \mathrm{M} \mathrm{CH} \mathrm{COONH}_{4}, \mathrm{pH}=7\right)$, carbonate (acid-soluble, $1 \mathrm{M} \mathrm{CH} \mathrm{COONH}_{4}$, $\mathrm{pH}=5)$, high oxidizable $\left(35 \% \mathrm{H}_{2} \mathrm{O}_{2}\right)$, reducible $\left(2 \mathrm{M} \mathrm{NH} \mathrm{NH}_{2} \mathrm{OH} \cdot \mathrm{HCl}\right.$ in $25 \% \mathrm{CH}_{3} \mathrm{COOH}$, $\mathrm{pH}=2)$, low oxidizable $\left(20 \% \mathrm{HNO}_{3}\right.$ and $\left.20 \% \mathrm{H}_{2} \mathrm{O}_{2}\right)$, and residual (mixture of mineral acids) fractions. Element abundances in the specimens were analyzed by ICP-MS on an $i C A P$ 6000 Series mass spectrometer. For the concentrations and speciation of $\mathrm{Hg}$, the core was sampled every $3 \mathrm{~cm}$. The $\mathrm{Hg}$ concentrations were determined by flameless AAS on an $R A$ 915M mercury analyzer with a PYRO-915+ pyrolysis attachment, following the M 03-092013 protocol. Mercury speciation was studied by the thermal release technique with atomic absorption detection [10].

\section{Results and discussion}

Water in the $\mathrm{Ur}$ impoundment has $\mathrm{pH}=7.3,0.34 \mathrm{~g} / \mathrm{L}$ TDS, and a Na-Mg-Ca- $-\mathrm{HCO}_{3}$ chemistry (mg/L: $173.9 \mathrm{HCO}_{3}, 60 \mathrm{Ca}, 5.2 \mathrm{Mg}, 3.6 \mathrm{Na} ; 0.24 \mathrm{Fe}, 0.0081 \mathrm{Al}, 16.73 \mathrm{SO}_{4}{ }^{2-}$, and $\left.1.3 \mathrm{Cl}^{-}\right)$. Heavy metals (HM) are partitioned unevenly between water (+ colloid) and particulate matter (Table 1). Dissolved HM are within the maximum allowable concentrations (MAC) for drinking and household uses (MAC1) approved in Russia. However, $\mathrm{Fe}, \mathrm{Cu}$ and $\mathrm{Hg}$ are above the allowable limit for fishery uses (MAC2), while the bulk contents of $\mathrm{Fe}$ and $\mathrm{Hg}$ (water+colloid) are twice the MAC 2 values (Table 1).

The bottom sediments, sampled to a depth of $33 \mathrm{~cm}$, consist of heterogeneous mud with organic layers and iron hydroxide stains. The core can be divided into four layers that differ in element content (Fig. 1): I (0 to $5 \mathrm{~cm}$ ), II $(5$ to $17 \mathrm{~cm})$, III $(17$ to $28 \mathrm{~cm}$ ) and IV (dark layer at a depth of $25 \mathrm{~cm}$ ). Fe increases from 5-6 wt.\% in layer I and $\sim 5 \mathrm{wt} . \%$ in II to $7-8$ wt. $\%$ in III, and even $15 \mathrm{wt} . \%$ at a depth of $24 \mathrm{~cm}$, slightly above layer IV. Cu is quite evenly distributed over the core $(\sim 50 \mathrm{ppm}$ in layer I, $\sim 70 \mathrm{ppm}$ in II, and $\sim 50 \mathrm{ppm}$ or locally up to $70 \mathrm{ppm}$ in III), but reaches $100 \mathrm{ppm}$ in layer IV. The contents of $\mathrm{Zn}$ are more variable: $200-250 \mathrm{ppm}$ in layer I, 300-400 ppm in II, about $100 \mathrm{ppm}$ in III, and $600 \mathrm{ppm}$ in IV (Fig. 1). Pb varies from 61-65 ppm in layer I to $100-130 \mathrm{ppm}$ in II, but is as low as $\sim 30$ 
ppm in III; layer IV is indistinguishable. Arsenic is distributed non-uniformly across the section: $46-86 \mathrm{ppm}$ in layer I; $52.6-100 \mathrm{ppm}$ in II, but is as low as $25-48 \mathrm{ppm}$ in III; As increase to $52-89 \mathrm{ppm}$ in layer IV. SR-XRF scanning at $23 \mathrm{keV}$ fails to resolve $\mathrm{Cd}$ and $\mathrm{Hg}$ variations, which require greater energy; their contents were estimated by sequential extraction $(\mathrm{Cd})$ and AAS (Hg). The bulk content of $\mathrm{Cd}$ is 0.75 to $5.12 \mathrm{ppm}(1.73 \mathrm{ppm}$ on average); $\mathrm{Hg}$ varies from 0.15 to $6.3 \mathrm{ppm}(2.73 \mathrm{ppm}$ on average): $\sim 4.53 \mathrm{ppm}$ in layer I, $\sim 4.9$ ppm in II, and $\sim 0.28$ ppm in III (Fig. 1).

Table 1. Heavy metals in Ur River, relative to MAC (ppm).

\begin{tabular}{ccccccc}
\hline Element & Water & $\begin{array}{c}\text { Particulate } \\
\text { matter }\end{array}$ & $\begin{array}{c}\text { Total } \\
\text { content }\end{array}$ & $\begin{array}{c}\text { \% in } \\
\text { Particulate matter }\end{array}$ & MAC(1) & MAC(2) \\
\hline $\mathrm{Fe}$ & $\mathbf{0 . 2 4}$ & $\mathbf{0 . 2 2}$ & $\mathbf{0 . 4 6}$ & 48 & $0.3(1)^{*}$ & 0.05 \\
$\mathrm{Cu}$ & $\mathbf{0 . 0 0 1 2}$ & 0.0004 & $\mathbf{0 . 0 0 1 6}$ & 25 & 1 & 0.001 \\
$\mathrm{Zn}$ & 0.0024 & 0.002 & 0.0044 & 45 & 1 & 0.01 \\
$\mathrm{Cd}$ & 0.000016 & 0.00002 & 0.000036 & 56 & 0.001 & 0.005 \\
$\mathrm{~Pb}$ & 0.00013 & 0.0013 & 0.00143 & 91 & 0.01 & 0.006 \\
$\mathrm{As}$ & 0.0009 & 0.0008 & 0.0017 & 47 & 0.01 & 0.05 \\
$\mathrm{Hg}(\mathrm{ppb})$ & $\mathbf{0 . 0 5 2}$ & 0.05 & $\mathbf{0 . 1 0 2}$ & 49 & 0.5 & 0.01 \\
\hline
\end{tabular}

Note: *reference value may be established by Principal public health officers for specific territories and water-supply systems; MAC(1): maximum allowable concentartion in drinking, houshold, and recreation waters (Public Health Norms, working documents HN-2.1.5.2280-07 and SanPiN2.1.5.980-00); $\operatorname{MAC}(2)$ : maximum allowable concentartion in waters used for fishery (Order by the Russian Ministry of Agriculture of 13.12.16 N 552).

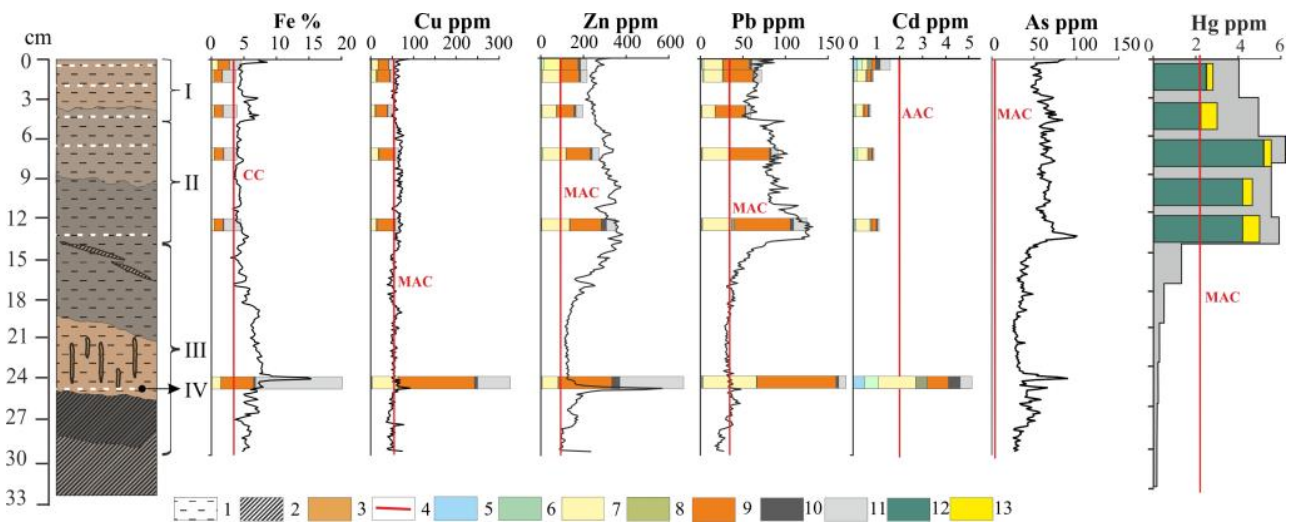

Fig. 1. Core depth profiles of heavy metals and $\mathrm{Hg}$ and their speciation. Black line shows element contents according to SR-XRF analysis. The core (left) is shown in its true colors; hatching symbols mark different particle sizes. 1 - mud; 2 - organic matter; 3 -iron hydroxide; 4 - maximum and approximate allowable concentrations (according to HN 2.1.7.2041-06; [13-14]) and average contents in upper continental crust (CC) [18]; 5-11 - sequential extraction fractions: water-soluble (5), exchangeable (6), carbonate (7), high-oxidizable (8), reducible (9), low-oxidizable (10), and residual (11); $12-\mathrm{MeHg}(\mathrm{org})$ species; $13-\mathrm{HgS}+\mathrm{HgSe}$ species; white dashed line marks horizons sampled for sequential extraction.

Layers I to III in the core correspond to element inputs into bottom sediments prior to mining and pollution (III), early during mining (II), and at present (I). The onset of AMD contamination is marked by a $\mathrm{Pb}$ peak at a depth of $12 \mathrm{~cm}$. Most of $\mathrm{Pb}$ resides in particulate matter suspended in water, and only small $\mathrm{Pb}$ percentages precipitate and migrate along the section. The element input was apparently the largest when the dispersion train began to form, but decreased gradually afterwards (layer II). Zn and As are partitioned evenly between water and particulate matter. The elements likewise increases in layer II but not as much as $\mathrm{Pb}$. $\mathrm{Cu}$ exists mostly in the dissolved form; it is evenly distributed along the 
section and increases only slightly in the beginning of mining (Fig. 1). Fe had a greater content prior to AMD inputs. At present (layer I), the contamination of bottom sediments is not very high. The contents of $\mathrm{Cu}$ decreased to their initial level but $\mathrm{Zn}$ and $\mathrm{Pb}$ are much above the values in layer III (prior to mining). The arsenic content, despite the fact that there are peaks in layer I, nevertheless does not exceed those for layer III. Although $\mathrm{Hg}$ is evenly partitioned between water and particulate matter, its pattern is most similar to that of $\mathrm{Pb}$, with a prominent peak in layer II; Hg speciation may vary seasonally [11]. Layer IV may be either a geochemical (or biochemical) barrier for vertical migration of elements or may record some earlier anthropogenic impacts.

Quite a large portion of $\mathrm{Cd}$ was recovered in water-soluble fraction (sulfates, chlorides, and soluble organic compounds), which accounts for 12 and $10 \%$ of its bulk content $(0.19$ and $0.5 \mathrm{ppm})$, at depths of $2-4 \mathrm{~mm}$ and $25 \mathrm{~cm}$, respectively, but for $5.5-7 \%$ only $(0.05-0.06$ $\mathrm{ppm})$ in other layers. The water-soluble fraction of other elements accounts for $2.4 \%$ of their bulk content. The percentage of $\mathrm{Cd}$ in exchangeable fraction is likewise the highest (5.6 to $16.1 \%$ or $0.06-0.6 \mathrm{ppm}$ ), but is lower for other elements: $0.45-1.8 \% \mathrm{Cu}, 0.45-5.3 \%$ $\mathrm{Zn}$, and $0.32-3.15 \% \mathrm{~Pb}$ (decreasing with depth), and $<0.5 \% \mathrm{Fe}$. High percentages of $\mathrm{Cd}$ (14.5-54 \%), Zn (11-40\%), Pb (27-30\%), Cu (17.5-28.6\%), and Fe (7-20\%) exist in carbonate fraction. The percentages of elements occurring in high-oxidizable fraction (organic compounds + high-oxidizable or authigenic sulfides) are: $12.1 \% \mathrm{Cd}, 5.83 \% \mathrm{Cu}$, $3.05 \% \mathrm{~Pb}, 1.1 \% \mathrm{Zn}$, and $<0.1 \% \mathrm{Fe}$. The highest percentages of most elements are in reducible fraction ( $\mathrm{Fe}$ and $\mathrm{Mn}$ oxides and hydroxides): $37-42 \% \mathrm{Zn}, 47-60 \% \mathrm{~Pb}$ and $44-$ $54.6 \% \mathrm{Cu}$; which also accounts for $25-39 \%$ of $\mathrm{Fe}$ and $10-23 \%$ of $\mathrm{Cd}$. Quite small amounts of elements were recovered in low-oxidizable fraction (sulfides more stable to oxidation): $6.5 \% \mathrm{Cu}, 4 \% \mathrm{~Pb}, 7 \% \mathrm{Zn}, 6.4 \% \mathrm{Al}$, and $3 \% \mathrm{Fe}$. Some percentages of all $\mathrm{HM}$ exist in residual fraction (aluminosilicates, quartz; Fig. 1). Speciation of arsenic as anionforming elements with variable oxidation degrees wasn't studied because requires special techniques of fractionation according to oxidation state or to types of compounds [12].

There are no specific norms for approximate (AAC) and maximum (MAC) allowable element concentrations in bottom sediments, and the concentrations of mobile HM species (water-soluble, exchangeable, and carbonate fractions) in the Ur bottom sediments were compared with MAC for soils (HN 2.1.7.2041-06; Fig. 1) [13-14]. The bulk concentrations of $\mathrm{Cd}$ and $\mathrm{Cu}$ are higher than AAC by factors of 2.5 and 6, respectively, in layer IV only $(25 \mathrm{~cm})$, while those of $\mathrm{Pb}$ and $\mathrm{Zn}$ are 5 and 6 times as high as MAC in layers I, II and IV. The bulk concentration of As are higher than MAC; the excess reaches 12, 25 and 50 times for the minimum, average and maximum contents, respectively (Fig. 1). Mercury (core average) exceeds the MAC of soils, being up to 3 times higher in some horizons. The total concentrations of mobile species exceed the MAC values for $\mathrm{Cd}$ (13.5 times), $\mathrm{Pb}$ (10.7 times), $\mathrm{Cu}$ (21.2 times), and $\mathrm{Zn}$ (5.8 times). Note for comparison that the above-MAC concentrations of mobile $\mathrm{Cu}, \mathrm{Zn}$ and $\mathrm{Pb}$ in the sediments of the Azov and Black seas, although being relatively low, have been interpreted as evidence of man-caused pollution of both sediments and water [13].

Mercury exists as methylated $\mathrm{MeHg}$ (org) and oxidized ( $\mathrm{HgS}+\mathrm{HgSe}$ ) species, but $\mathrm{MeHg}$ (org) predominates (core average of $3.58 \mathrm{ppm}$ ) and exceeds the maximum allowable $\mathrm{Hg}$ concentration in soil $(2.1 \mathrm{ppm})$. The oxidized $\mathrm{Hg}$ species $(0.67 \mathrm{ppm}$ on average) may include sulfides and selenides. The 2 species were found to be predominant in cyanide wastes of the Novo-Ursk deposit [6]. Their presence may indicate that the material of wastes can either migrate to a distance of $3 \mathrm{~km}$ downstream of AMD discharge into the Ur River or form in situ. Methyl mercury, which is stable and capable of accumulation, poses the greatest hazard for the environment [15].

The pollution level of bottom sediments is often measured via enrichment factor (EF, current-to-initial element concentration ratio) [16] or bottom accumulation coefficient 
(BAC, sediment-to-water element concentration ratio) [17]. Elements in bottom sediments have $\mathrm{EF}$ values of 25 for $\mathrm{Hg}, 12.1$ for $\mathrm{Cd}, 9.2$ for $\mathrm{Pb}, 3.96$ for $\mathrm{As}, 0.77$ for $\mathrm{Zn}, 0.6$ for $\mathrm{Fe}$ and 0.35 for $\mathrm{Cu}$. The total pollution estimated as an EF sum is 51.8, which corresponds to a hazardous level. According to the criteria for BAC estimation $\left(n \cdot 10-n \cdot 10^{2}\right)$, the bottom sediments of the Ur impoundment are constantly receiving fresh inputs of $\mathrm{Hg}(\mathrm{BAC}=27)$. The respective coefficients for $\mathrm{Fe}\left(117 \cdot 10^{3}\right), \mathrm{Pb}\left(55 \cdot 10^{3}\right), \mathrm{Zn}\left(52 \cdot 10^{3}\right), \mathrm{Cd}\left(48 \cdot 10^{3}\right), \mathrm{Cu}$ $\left(36 \cdot 10^{3}\right)$ and As $\left(28 \cdot 10^{3}\right)$ correspond to stable high pollution $\left(n \cdot 10^{3}-n \cdot 10^{4}\right)$, with the contaminants markedly exceeding the MAC levels.

\section{Conclusions}

Enrichment of bottom sediments in elements that migrate through water depends on their speciation. For instance, $\mathrm{Pb}$ which resides mostly in particulate matter causes stronger pollution than $\mathrm{Cu}$ existing mostly as dissolved species. The $\mathrm{Pb}$ profile in the 'water-bottom sediment' system provides a reliable marker of pollution beginning in the Ur impoundment. The contents of several HM exceed the MAC values, but $\mathrm{Hg}$ poses the greatest hazard as it occurs as a highly toxic $\mathrm{MeHg}(\mathrm{org})$ species.

Field trip and geochemical analyses were done on state assignment of IGM SB RAS at the Analytical Center for multi-elemental and isotope research SB RAS (Novosibirsk), partly. The study was additionally supported by grant 18-77-10056 from the Russian Science Foundation (SR-XRF analyses and work with translation of publication).

\section{References}

1. D. Pipoyan, M. Beglaryan, L. Costantini, R. Molinari, N. Merendino, Hum. \& Ecol. Risk Ass.: An Inter. J., 24(2), 317-330 (2018)

2. T.Yu. Kalavriy, Ostrovskie Chteniya, 1, 152-156 (2014)

3. Yu.V. Robertus, A.V. Puzanov, R.V. Lubimov, Geogr. \& Prirod. Res., 3, 48-55 (2015)

4. I.N. Shcherbakova, M.A. Gustaitis, E.V. Lazareva, A.A. Bogush, Chem. Sustain. Devel., 535-547 (2010)

5. Z.E. Pukhaeva, Gornyi Inform.-Analit. Bull. (Sci. \& Engin. J.), 1, 95-96 (2005)

6. M.A. Gustaytis, E.V. Lazareva, A.A. Bogush, O.V. Shuvaeva, I.N. Shcherbakova, E.V. Polakova, Zh.O. Badmaeva, G.N. Anoshin, Dok. Earth Sci. 432 (Part 2), 778-782 (2010)

7. I.N. Myagkaya, E.V. Lazareva, M.A. Gustaytis, S.M. Zhmodik, J. Geochem. Expl. 160, 16-30 (2016)

8. B.Yu. Saryg-ool, I.N. Myagkaya, I.S. Kirichenko, M.A. Gustaytis, O.V. Shuvaeva, S.M. Zhmodik, E.V. Lazareva, Sci. Tot. Envir., 581-582, 460-471 (2017)

9. M.A. Phedorin, E.L. Goldberg, Rus. Geol \& Geoph., 49 (1), 40-45 (2008)

10. O.V. Shuvaeva, M.A. Gustaytis, G.N. Anoshin, Analyt. Chim. Act., 621, 148-154 (2008)

11. M.A. Gustaytis, I.N. Myagkaya, B.Yu. Saryg-ool, E.V. Lazareva, VestnIk VGU, Ser. Geol., 4, 114-122 (2017)

12. C. Gleyzes, S. Tellier, M. Astruc, Trend.analyt.chem., 21(6-7), 451-467 (2002)

13. P.I. Kurilov, R.P. Kruglyakova, N.I. Savitskaya, P.S. Fedotov. Nauka Kubani, 4, 64-68 (2008) 
14. L.R. Gazilova, S.I. Yanturin, G.A. Yagafarova, Vestnik OGU, 6, 552-553 (2009; in Russian)

15. L.I. Kuzubova, O.V. Shuvaeva, G.N. Anoshin. Methyl Mercury in the Environment (Distribution, Natural Formation, and Detection Methods) (2000; in Russian)

16. O.V. Sokolova, Migration of Heavy Metals in the 'Water-Bottom Sediment' System in a Zone of Anthropogenic Impact: An Experimental Study and Thermodynamic Calculations. (2008; in Russian)

17. A.M. Nikanorov, A.G. Stradomskaya, Water Resources, 34 (3), 314-320 (2007)

18. S.R. Taylor, S.M. McLennan, Rev. Geoph., 33, 241-265 (1995) 